Canadian

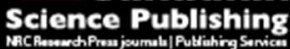

Canadian Journal of Zoology Revue canadienne de zoologie

\title{
Survival and osmoregulation of the purple marsh crab (Sesarma reticulatum) at varying salinity and $\mathrm{pH}$
}

\begin{tabular}{|r|l|}
\hline Journal: & Canadian Journal of Zoology \\
\hline Manuscript ID & cjz-2016-0199.R1 \\
\hline Danuscript Type: & Note \\
\hline Complete List of Authors: & $\begin{array}{l}\text { Shaughnessy, Ciaran; DePaul University, Biological Sciences } \\
\text { Anderson, Elsa; DePaul University, Biological Sciences } \\
\text { Kasparian, Mary; DePaul University, Biological Sciences } \\
\text { LaMontagne, Jalene; DePaul University, Biological Sciences } \\
\text { Bystriansky, Jason; DePaul University, Biological Sciences }\end{array}$ \\
\hline Keyword: & $\begin{array}{l}\text { Purple marsh crab, Sesarma reticulatum, OSMOREGULATION < Discipline, } \\
\text { salinity, pH, estuary }\end{array}$ \\
\hline \multicolumn{2}{|c}{} \\
\hline
\end{tabular}

SCHOLARONE ${ }^{\text {tw }}$

Manuscripts 
1 Survival and osmoregulation of the purple marsh crab (Sesarma reticulatum) at varying

2 salinity and $\mathbf{p H}$

3

4 C.A. Shaughnessy, E.C. Anderson, M. Kasparian, J.M. LaMontagne, and J.S. Bystriansky

5

6 Affiliations:

7 Department of Biological Sciences, DePaul University, 2325 North Clifton Ave. Chicago, IL, $8 \quad 60614$

9

10 Email addresses:

11 CAS: cshaughnessy@umass.edu

12 ECA: eholden2@uic.edu

13 MK: kasparian.mary@gmail.com

14 JML: jlamont1@depaul.edu

15 JSB: jbystria@depaul.edu

16

17 Corresponding author: Ciaran A. Shaughnessy ${ }^{1}$

18 Department of Biological Sciences, DePaul University

192325 North Clifton Ave. Chicago, IL, 60614

${ }^{1}$ Current affiliation and contact information for CAS:

Organismic and Evolutionary Biology, University of Massachusetts

204C French Hall, Amherst, MA 01003

Phone: (413) $863-3860$

Fax: (413) $863-9180$ 
Survival and osmoregulation of the purple marsh crab (Sesarma reticulatum) at varying salinity and pH

\section{C.A. Shaughnessy, E.C. Anderson, M. Kasparian, J.M. LaMontagne, and J.S. Bystriansky}

\section{ABSTRACT}

Overfishing of top predators along the western Atlantic coastline has led to a trophic cascade in salt marshes, with increases in herbivorous purple marsh crab (Sesarma reticulatum; Say, 1817) abundances in North American estuaries leading to overgrazing of cordgrass (Spartina alterniflora, Loisel.) and shoreline erosion. To evaluate potential physiological limits on the range of $S$. reticulatum within an estuary, we evaluated survival and physiological tolerance of S. reticulatum from the Ashepoo-Combhee-Edisto (ACE) River Basin in South challenges, representative of estuarine extremes. Survival, haemolymph ion concentrations, and gill $\mathrm{Na}^{+} / \mathrm{K}^{+}$-ATPase (NKA) and V-type $\mathrm{H}^{+}$-ATPase (VHA) activity were measured after a 48-hr exposure to each experimental condition. Survival was nearly $100 \%$ and osmoregulatory control robust to all potential combinations of salinity and $\mathrm{pH}$ stressors examined in this study, and therefore are likely unrestricted in their fundamental niche based on these stressors throughout an estuary. 


\section{3}

\section{INTRODUCTION}

Salt marsh habitat loss along the western Atlantic coast has become an increasing

problem in the last 40 years (Bertness et al. 2014). The pronounced vegetation die-off is believed to be due to changes in trophic structure (Silliman and Bertness 2002; Bertness and Silliman 2008). Shifts in the abundance of one or several key species within a community are known to have cascading effects on populations of other species and broader impacts on the ecosystem. Top-down effects result from predator removal, which increases herbivore populations and consequently decreases vegetation cover (Hughs et al. 2013). In salt marshes especially, this decrease in vegetation can lead to erosion and habitat loss (Nyman et al. 1994). We can therefore reasonably expect the spatial scale of estuarine habitat loss to be based on both (1) the spatial scale of predator removals and (2) key environmental variables that influence the physiological limits of the herbivore.

The purple marsh crab (Sesarma reticulatum; Say, 1817) is an herbivorous crab native to salt marshes along the east coast of North America, ranging from Massachusetts to southern Florida (Abele 1973). In the past 20 years, commercial and recreational fishing of natural predators to $S$. reticulatum (e.g., blue crab, striped bass, and Atlantic cod) has resulted in the rapid over-population of $S$. reticulatum in many salt marsh ecosystems along the eastern coast of the United States (Silliman and Bertness 2002; Bertness and Silliman 2008). With fewer predators, root and aboveground biomass consumption of smooth cordgrass (Spartina alterniflora, Loisel.) by $S$. reticulatum has risen dramatically, resulting in severe salt marsh erosion (Holdredge et al. 2009). This loss of salt marsh habitat has severe consequences not only for the health of the ecosystem, but also for the economic and recreational use of the shoreline and coastal waterways. If such primary consumption remains uncontrolled by natural predators, 
the extent of herbivory by S. reticulatum and subsequent potential salt marsh erosion could extend throughout the coastal environment where S. reticulatum is found. Sesarma reticulatum is highly mobile and displays low habitat fidelity (Seiple and Salmon 1982), suggesting that expansion of these populations will depend largely on the physiological capacity of $S$. reticulatum to survive in the dynamic salt marsh environment.

Salt marshes are coastal habitats often adjacent to estuaries which undergo daily fluctuations in environmental factors due to river outflow and tidal influence. To survive in an estuarine habitat, many organisms, including crabs, have a suite of physiological adaptations which allow them to tolerate fluctuations in their abiotic environment. These adaptations set the physiological niche for these organisms (Basset et al. 2013) and define the habitat range over which they may be found. In an estuary, the daily rising and retreating tide produces large fluctuations in salinity (between 2 and $32 \%$; Bulger et al. 1993). The lower salinity tolerance limit of most estuarine invertebrates overlaps the upper salinity tolerance limit of most freshwater invertebrates, between 2 and $4 \%$ ( $50-100 \mathrm{mOsm} \cdot \mathrm{kg}^{-1}$; Bulger et al. 1993). Conversely, the upper salinity tolerance for most estuarine invertebrates overlaps the lower salinity tolerance limits for many stenohaline (i.e., obligate) marine species between 24 and 27 $\%$ ( $\left.700-800 \mathrm{mOsm} \cdot \mathrm{kg}^{-1}\right)$. For an osmoregulating estuarine invertebrate (such as $S$. reticulatum), these lower and upper salinity boundaries describe the theoretical lower and upper limits of osmoregulatory control, within which $S$. reticulatum is able to maintain internal osmotic pressure by actively regulating ion and water balance. Within this range, S. reticulatum hyperosmoregulates to maintain an internal osmolality around $700 \mathrm{mOsm} \cdot \mathrm{kg}^{-1}$ (at or above that of the environment) (Foskett 1977; Staton and Felder 1992). Estuarine organisms unable to meet this hyper-osmoregulatory demand might experience excessive ion loss to and water gain from the 
89

90

91

92

93

94

95

96

97

more dilute environment. There is evidence that the degree of osmoregulatory ability in $S$. reticulatum is habitat- and population-specific (Stanton and Felder 1992), and therefore could reasonably be impacted by other fluctuating environmental factors.

The mechanism of hyper-osmoregulation in estuarine crabs is accomplished by a suite of primary and secondary ion transport proteins on the gill epithelium. The activity of the $\mathrm{Na}^{+}-\mathrm{K}^{+}-$ ATPase (NKA) in mitochondria-rich cells produces a local electrogenic gradient favoring ion (primarily $\mathrm{Na}^{+}$and $\mathrm{Cl}^{-}$) uptake across the gill epithelium (Lucu et al. 2000). In many euryhaline crabs, the apically located vacuolar-type $\mathrm{H}^{+}$-ATPase (VHA), too, is utilized in ion $\left(\mathrm{Na}^{+}\right)$uptake from dilute environments (Tsai and Lin 2007). Alongside changes in salinity, shifts in local environmental factors such as the input from agricultural runoff, products of organic matter decomposition, and poor water mixing can cause fluctuations in local ambient $\mathrm{pH}$ between $\mathrm{pH}$ 6.0 and pH 8.5 (Berounsky and Nixon 1993; Feely et al. 2010). Physiological processes of acidbase balance and nitrogen excretion may also be under frequent acute stress (Tsai and Lin 2007). Compensation for these $\mathrm{pH}$ challenges by estuarine invertebrates, although much less studied than osmoregulation, is also reported to be fulfilled in part by the acid $\left(\mathrm{H}^{+}\right)$excretion path associated with VHA activity (Weihrauch et al., 2001).

Research on salinity acclimation and acid-base regulation in crabs typically looks at the effects of these stressors in isolation. However, the multitude of simultaneous changes in the abiotic estuarine environment is an example of the need for more multiple stress analyses in ecophysiology research. Estuarine and migrating organisms continuously experience an array of new environmental challenges, and multiple stressor analyses offer a larger window through which we can study the physiology associated with these environmental challenges. When the physiological analysis is more comprehensive of the natural environmental stressors, we can 
112 draw more powerful ecological inferences from these physiological data (Todgham and Stillman 113 2013).

This study investigated the effects of varying both ambient salinity and $\mathrm{pH}$ levels,

115 representative of hypothetical limits experienced along an estuarine gradient, on the

116 osmoregulatory capacity of S. reticulatum collected from the field. Although physiological

117 responses to changes in salinity in S. reticulatum have been documented (Foskett 1977; Staton

118 and Felder 1992), to our knowledge no other studies have evaluated responses to simultaneous

119 salinity and $\mathrm{pH}$ changes, representative of what these animals may encounter in an estuarine

120 environment. Ecological inferences made from these multiple stressor data could be useful for

121 predicting the potential range of $S$. reticulatum populations within estuaries. Presuming $S$.

122 reticulatum is well-adapted to the environment it inhabits, we predicted that survival and

123 osmoregulatory capacity of $S$. reticulatum would be robust to changes in ambient $\mathrm{pH}$ and salinity

124 between observed estuarine limits. This would be evidenced by the maintenance of

125 osmoregulatory control at dilute salinities, regardless of ambient $\mathrm{pH}$, and would indicate the

126 potential for successful habitation by S. reticulatum (and thus, cordgrass consumption and

127 shoreline erosion) throughout estuaries if the current decline in its natural predators persists.

129 MATERIALS AND METHODS

Field location and animal collection site

We collected adult $S$. reticulatum $(48 \mathrm{M}, 48 \mathrm{~F}$; carapace width $=18.7 \pm 0.2 \mathrm{~mm}$; weight $=$ $1323.7 \pm 0.1 \mathrm{~g}$ ) from the top $0.25 \mathrm{~m}$ of sediment along a $125 \mathrm{~m}$ stretch of muddy berm of the 133 intertidal region found near the junction of Mosquito Creek and the Ashepoo River (UTM Zone $13417361792,3602357)$. These estuaries are in the Ashepoo-Combhee-Edisto (ACE) Basin in 
135 South Carolina, the second largest watershed in the continental United States which includes

$1361,400 \mathrm{~km}^{2}$ of riparian and estuarine habitats, and $540 \mathrm{~km}^{2}$ of protected estuarine habitat (SC DNR

137 and NOAA). These undeveloped stretches of salt marshes are characterized by the presence of $S$.

138 alterniflora, a prominent food source for S. reticulatum across its range (Haines and Montague 139 1979).

140

Handling and sampling protocol

Immediately after collection, we placed S. reticulatum in individual porous holding

143 vessels $(0.35 \mathrm{~L})$ to reduce direct handling, eliminate unwanted interactions between individuals, 144 and allow for proper water mixing and exposure. We acclimatized $S$. reticulatum over $36 \mathrm{~h}$ to 145 water conditions that were representative of the water at the site of collection $\left(18^{\circ} \mathrm{C}, \mathrm{pH} 7.6,30\right.$ 146 $\%$ ). Following acclimatization, we randomly assigned individuals to treatments $(n=18)$ where

147 they were acutely exposed to one of six combinations of two salinity ( 5 and $30 \%$ ) and three $\mathrm{pH}$ 148 (pH 6.6, 7.6, and 8.6) experimental water conditions. This range of salinities was chosen to 149 represent salinities near the limits of the ACE Basin according to water quality data accessed 150 through the National Estuarine Research Reserve System (NERRS, 2012). Individuals were held 151 under these conditions at $18^{\circ} \mathrm{C}$ for $48 \mathrm{~h}$. We created diluted salinity treatments from natural 152 seawater using dechlorinated freshwater; and manipulated $\mathrm{pH}$ to acidotic or basic conditions by 153 the addition of hydrochloric acid $(\mathrm{HCl})$ or sodium hydroxide $(\mathrm{NaOH})$, respectively. We checked $154 \mathrm{pH}$ hourly and maintained levels within 0.1 units of the target $\mathrm{pH}$. At the conclusion of the acute exposure, we euthanized crabs by destroying the dorsal 156 ganglion, and immediately sampled for haemolymph and gill. We drew hemolymph from the 157 venus sinus by puncturing the arthrodial membrane between the fourth and fifth pereiopod using 
158 a 22-gauge needle coated with a $10 \%$ sodium citrate anticoagulant. We removed all gill arches

159 from the left side, flash-froze haemolymph and gill samples in liquid nitrogen, and stored

160 samples at $-80^{\circ} \mathrm{C}$ until analysis.

161

162

Haemolymph ion analysis

We measured all haemolymph ion concentrations in duplicate following manufacturer protocols; haemolymph $\left[\mathrm{Cl}^{-}\right]$using a digital chloridometer (ChloroChek, Wescor, Inc., Logan, UT), haemolymph $\left[\mathrm{Na}^{+}\right]$by emission flame photometry (Jenway PFP7, Bibby Scientific Ltd.,

166

167 168

169 175 albumin standard.

\section{Tissue analysis}

We prepared excised gill samples on ice in a ground glass manual homogenizer (\#410, Will Scientific, Inc., Rochester, NY) in $500 \mu \mathrm{L}$ of a homogenizing medium (250 mM sucrose, 10 mM EDTA, $50 \mathrm{mM}$ imidazol, $0.1 \%$ sodium deoxycholate; $\mathrm{pH} 7.5)$, then centrifuged at $4000 \mathrm{~g}$ for 2 min. We spectrophotometrically (595) measured protein content of the crude homogenates using the Bradford protein assay (BioRad Laboratories, Richmond, CA) with a bovine serum

We assayed NKA and VHA activity in duplicate by incubating $10 \mu \mathrm{L}$ of homogenized gill in $300 \mu \mathrm{l}$ of solution designed to either activate (assay solution $A$ ) or inhibit (assay solution $B$ ) the enzyme. Assay solution $A$ contained (in $\mu \mathrm{M}$ ) $100 \mathrm{NaCl}, 12.5 \mathrm{KCl}, 5 \mathrm{MgCl}_{2}, 0.1 \mathrm{EDTA}, 15$ imidazole, and $0.04 \mathrm{Na}_{2}$-ATP. Assay solution $B$ was identical to solution $A$, except $\mathrm{KCl}$ was omitted and $1 \mathrm{mM}$ of an enzyme-specific inhibitor (ouabain inhibits NKA, bafilomycin inhibits 
181 VHA) was added. After incubation at $18{ }^{\circ} \mathrm{C}$ for $30 \mathrm{~min}$, we stopped the reaction by adding 500 $182 \mu \mathrm{L}$ of an ice-cold stopping solution $(39.6 \mathrm{~mL} 0.538 \mathrm{M} \mathrm{HCl}, 1.29 \mathrm{~g}$ ascorbic acid, $2.13 \mathrm{~mL} 10 \%$ 183 ammonium molybdate, and $3.3 \mathrm{~mL} \mathrm{20 \%} \mathrm{SDS).} \mathrm{We} \mathrm{spectrophotometrically} \mathrm{(850} \mathrm{nm)} \mathrm{measured}$ 184 inorganic phosphate $\left(\mathrm{P}_{i}\right)$ liberated via hydrolysis of ATP during incubation as a 185 phosphomolybdate complex. We determined NKA- and VHA-specific ATPase activity by 186 calculating the difference in $\mathrm{P}_{i}$ liberation between the uninhibited and respective enzyme187 inhibited solutions.

Statistical analysis

To test whether the survival of individuals was associated with the treatment exposure, 191 we used a chi-square analysis. To assess the main effects of salinity and $\mathrm{pH}$ and any potential 192 interactions between the two, on $\left[\mathrm{Na}^{+}\right],\left[\mathrm{Cl}^{-}\right]$, osmolality, and NKA and VHA activity as 193 univariate response variables, we used two-way Analysis of Variance (ANOVA) testing. The 194 data conformed to the equal variance assumption of ANOVA based on $F_{\max }$ tests. We ran 195 Tukey's post-hoc analyses to determine significant differences between treatments following 196 significant ANOVA results. We conducted all statistical analyses using R statistical software 197 (Version 3.2.2).

\section{RESULTS}

200 Survival

We observed high survival rates ( $>99$ percent) in all experimental conditions. Survival 202 was not significantly different between treatments $\left(X^{2}{ }_{5}=5.035 ; P=0.4116\right)$. The single 203 mortality occurred in the $30 \%$ salinity, $\mathrm{pH} 6.6$ experimental treatment. Irrespective of the 
204

205

206

207

208

209

210

211

212

213

214

215

216

217

218

219

220

221

222

223

224

225

226

combination of $\mathrm{pH}$ and salinity stressors, crabs appeared to be fully-responsive after the 48-hour exposure with no visible or physiological signs of poor health.

\section{Haemolymph ions}

Haemolymph $\left[\mathrm{Na}^{+}\right]$was slightly (although not significantly) higher in all $30 \%$ salinity treatments compared to the $5 \%$ at the equivalent $\mathrm{pH}$ (Fig. 1). There was no significant effect on haemolymph $\left[\mathrm{Na}^{+}\right]$by $\mathrm{pH}\left(F_{2,35}=1.02, P=0.370\right)$, salinity $\left(F_{1,35}=3.99, P=0.054\right)$, or the interaction of $\mathrm{pH}$ and salinity $\left(F_{2,35}=0.01, P=0.986\right)$. There was a significant effect of salinity on haemolymph $\left[\mathrm{Cl}^{-}\right]\left(F_{1,95}=4.77, P=0.031\right)$, with $\left[\mathrm{Cl}^{-}\right]$trending higher in the higher salinity, but there was no significant effect of $\mathrm{pH}\left(F_{2,95}=0.91, P=0.408\right)$ or the interaction $\left(F_{2,95}=0.73\right.$, $P=0.485)$ (Fig. 1). Haemolymph osmolality was significantly increased by salinity $\left(F_{1,40}=24.7\right.$, $P<0.001$ ) (Fig 1.). Osmolality trended higher at higher $\mathrm{pH}$ levels but no significant effect on osmolality was observed due to differences in $\mathrm{pH}\left(F_{2,40}=1.23, P=0.303\right)$ or the interaction of $\mathrm{pH}$ and salinity $\left(F_{2,40}=0.07, P=0.933\right)$.

\section{Gill enzyme activity}

Gill NKA activity remained relatively stable across experimental conditions, though it was significantly affected by the interaction of salinity and $\mathrm{pH}$ stressors $\left(F_{2,98}=3.59, P=0.031\right)$ (Fig. 2). At $\mathrm{pH} 8.6$, NKA activity was higher in the $30 \%$ than the $5 \%$ salinity condition; at $\mathrm{pH}$ 6.6, NKA activity was higher in $5 \%$ than $30 \%$. There was no significant effect on NKA activity by $\mathrm{pH}\left(F_{2,98}=0.73, P=0.484\right)$ or salinity $\left(F_{1,98}=0.01, P=0.928\right)$ alone. Gill VHA activity appeared to increase in $5 \%$ at each $\mathrm{pH}$, but there was no significant effect of either $\mathrm{pH}$ $\left(F_{2,19}=1.09, P=0.355\right)$, salinity, $\left(F_{2,19}=1.92, P=0.182\right)$, or the interaction $\left(F_{1,19}=0.94, P=\right.$ 
$2270.409)$.

228

229

\section{DISCUSSION}

High survival rates and normal osmoregulatory function observed in this study indicate $S$. reticulatum is well-adapted to tolerate simultaneous stressors of $\mathrm{pH}$ and salinity. The relatively

232 small changes in haemolymph ion concentrations upon exposure to dilute seawater agree with 233 haemolymph ion data obtained from single stressor salinity studies on S. reticulatum and other 234 osmoregulating salt marsh crab species (Foskett 1977; Staton and Felder 1992; Tsai and Lin 235 2007). Had the additional challenge of changes in $\mathrm{pH}$ limited the ability of the crab to hyper236 osmoregulate, there may have been greater ion loss in the dilute salinity. conditions. Greater up- or down-regulation of enzyme activity may have been observed if the exposures to these experimental conditions were longer, but a 48-hour exposure is already longer than expected from the $\sim 12$-hour tidal cycle seen in the ACE Basin. The significant interaction of salinity and $\mathrm{pH}$ on gill NKA activity is apparent by the opposite relationship between NKA

242 activity in $5 \%$ and $30 \%$ to decreasing ambient $\mathrm{pH}$ - as $\mathrm{pH}$ decreases gill NKA activity

243 increases in the $5 \%$ group, and decreases in the $30 \%$ group. That the persistence of NKA 244 activity was however within a normal range of regulatory response for estuarine crabs (Tsai and 245 Lin, 2007) across these environmental conditions, coupled with the relatively stable haemolymph 246 ion concentrations, indicates uninterrupted osmoregulatory function and demonstrates adaptation

247 to these simultaneous environmental stressors. Likewise, the increase in VHA activity upon 248 exposure to $5 \%$ salinity is consistent with the established role of this enzyme in hyper249 osmoregulation (i.e., $\mathrm{Na}^{+}$uptake) in crabs in dilute seawater (Tsai and Lin 2007). These ion and 
250

251

252

253

254

255

256

257

258

259

260

261

262

263

264

265

266

267

268

269

270

271

272

enzyme activity data suggest that even at the limits of hypothetical simultaneous salinity and $\mathrm{pH}$ challenges within an estuary, S. reticulatum appears to maintain normal osmoregulatory function.

Historically, biologists thought that major anthropogenic disturbances to estuaries only had a 'bottom-up' origin (Bertness et al. 2008; Bertness and Ellison 1987; Teal 1962), wherein human-induced shifts in abiotic factors (e.g., increases in pollutants or nutrients, rising water levels, acidification due to elevated atmospheric $\mathrm{CO}_{2}$, etc.) have been the drivers for the widespread loss of primary producers. However, such loss may also (or even more so) be attributed to a 'top-down' imbalance, wherein the overharvesting of secondary consumers reduces the predation on primary consumers (Bertness et al. 2014; Silliman and Bertness 2002; Silliman and Zieman 2001; Strong 1992). This appears to be the case with the overharvesting of natural predators to the marsh crab $S$. reticulatum, resulting in increasingly uncontrolled primary consumption by these crabs (Bertness and Silliman 2008).

Up to this point, osmoregulatory studies on estuarine-adapted crabs have looked mainly at the effects of salinity alone. However, there is clear difference in ambient $\mathrm{pH}$ across salinities in an estuary. The natural salinity and $\mathrm{pH}$ of the water in the upper regions of an estuary (freshwater; $\mathrm{pH}$ 6.5-7.5) are both lower than in the lower regions of the estuary (highly-buffered seawater; $\mathrm{pH}$ 7.5-8.5). If differences in $\mathrm{pH}$ limit the osmoregulatory ability of S. reticulatum as it moves throughout an estuary, the range of S. reticulatum in the ACE Basin as defined by its salinity tolerance may be currently over-estimated. If so, the potential geographical range of cordgrass consumption by $S$. reticulatum may also be over-estimated. The results of this study, however, do not indicate that physiological interaction of salinity and $\mathrm{pH}$ on $\mathrm{S}$. reticulatum osmoregulation is sufficient to limit survival, salinity tolerance, or $\mathrm{pH}$ tolerance. Although further ecological study of this system is necessary, these results indicate the possibility of an 
273 expansion, based on physiological tolerances, of the realized niche of $S$. reticulatum. An

274 expansion of $S$. reticulatum could have potential negative consequences on cordgrass and 275 subsequent shoreline erosion through increased consumption within this basin.

276 


\section{ACKNOWLEDGEMENTS}

278 Funding for this project was provided though DePaul University grants to JML and JSB

279 and the DePaul University Department of Biological Sciences. Research space and

280 accommodation were provided by the South Carolina Department of Natural Resources. The

281 authors thank Dr. Al Segers for his support, advice and valuable insight while in South Carolina.

282 Additionally, the authors thank G. Einhorn, L. Younes, R. Wenkus, K. Hermann, and D. Moore

283 for their support and assistance with collecting and processing samples. 
284

285

286

287

288

289

290

291

292

293

294

295

296

297

298

299

300

301

302

303

304

305

306

\section{REFERENCES}

Abele, L. G. 1973. Taxonomy, distribution and ecology of the genus Sesarma (Crustacea, Decapoda, Grapsidae) in eastern North America, with special reference to Florida. Am. Midl. Nat. 90:375-386.

Basset, A., Elliott, M., West, R. J., Wilson, J. G. 2013. Estuarine and lagoon biodiversity and their natural goods and services. Estuar. Coast. Shelf Sci. 132:1-4.

Berounsky, V. M., Nixon, S. W. 1993. Rates of nitrification along an estuarine gradient in Narragansett Bay. Estuaries, 16:718-730.

Bertness, M.D., Brisson, C. P., Coverdale, T. C., Bevil, M. C., Crotty, S. M., and Suglia, E. R. 2014. Experimental predator removal causes rapid salt marsh die-off. Ecol. Lett. 17: 830835.

Bertness, M. D., and Ellison, A. M. 1987. Determinants of pattern in a New England salt marsh plant community. Ecol. Monogr. 57:129-147.

Bertness, M. D., and Silliman, B. R. 2008. Consumer control of salt marshes driven by human disturbance. Conserv. Biol. 22:618-623.

Bertness, M. D., Crain, C., Holdredge C., and Sala, N. 2008. Eutrophication and consumer control of New England salt marsh primary productivity. Conserv. Biol. 22:131-139.

Bulger, A. J., Hayden, B. P., Nelson, D. M., and Geraldine, M. 1993. Estuarine salinity zones derived from a multivariate analysis. Estuaries, 16:311-322.

Feely, R. A., Alin, S. R., Newton, J., Sabine, C. L., Warner, M., Devol, A., Krembs, C., and Maloy, C. 2010. The combined effects of ocean acidification, mixing, and respiration on pH and carbonate saturation in an urbanized estuary. Estuar. Coast. Shelf Sci. 88:442449. 
Foskett, J.K. 1977. Osmoregulation in the larvae and adults of the grapsid crab Sesarma reticulatum (Say). Biol. Bull. (Woods Hole), 153:505-526.

Haines, E. B., and Montague, C. L. 1979. Food sources of estuarine invertebrates analyzed using ${ }^{13} \mathrm{C} /{ }^{12} \mathrm{C}$ ratios. Ecology, 60:48-56.

Holdredge, C., Bertness, M. D., and Altieri, A. H. 2009. Role of crab herbivory in die-off of New England salt marshes. Conserv. Biol. 23:672-679.

Hughs, B. B., Eby, R., Van Dyke, E., Tinker, M. T., Marks, C. I., Johnson, K.S., Wasson, K. 2013. Recovery of a top predatory mediates negative eutrophic effects on seagrass. Proc. Natl. Acad. Sci. U.S.A. 110(38):15313-15318.

Lucu, Č., Devescovi, M., Skaramuca, B., and Kozul, V. 2000. Gill Na, K- ATPase in the spiny lobster Palinurus elephas and other marine osmoconformers: adaptiveness of enzymes from osmoconformity to hyperregulation. J. Exp. Mar. Biol. Ecol. 246:163-178.

NERRS (NOAA National Estuarine Research Reserve System). 2017. System-wide Monitoring Program. Data accessed from the NOAA NERRS Centralized Data Management Office website: http://www.nerrsdata.org.

Nyman, J. A., Carloss, M., Delaune, R. D., Patrick JR, W. H. 1994. Erosion rather than plant dieback as the mechanism of marsh loss in an estuarine marsh. Earth Surf. Proc. Land. 19(1):69-84.

Say, T. 1817. An account of the Crustacea of the United States. J. Acad. Nat. Sci. Phila. 1:57-63

Seiple, W., and Salmon, M. 1982. Comparative social behavior of two grasped crabs, Sesarma reticulatum (Say) and S. cinereum (Bosc). J. Exp. Mar. Biol. Ecol. 62:1-24.

Silliman, B. R., and Bertness, M. D. 2002. A trophic cascade regulates salt marsh primary production. Proc. Natl. Acad. Sci. U.S.A. 99:10500-10505. 
330 South Carolina Department of Natural Resources and National Oceanic and Atmospheric

331

332

334 335 336 337 338 339 340 341 342 343 344 345 346 Administration, Coastal Services Center. Characterization of the Ashepoo-CombaheeEdisto (ACE) Basin, South Carolina. 2000. Available from dnr.sc.gov/marine/mrri/acechar [accessed 08 December 2013]

Staton, J. L., and Felder, D. L. 1992. Osmoregulatory capacities in disjunct western Atlantic populations of the Sesarma reticulatum complex (Decapoda: Grapsidae). J. Crustac. Biol. 12:335-341.

Strong, D. R. 1992. Are trophic cascades all wet? Differentiation and donor-control in speciose ecosystems. Ecology, 73:747-754.

Teal, J. M. 1962.Energy flow in the salt marsh ecosystem of Georgia. Ecology 43:614-624.

Todgham, A. E., and Stillman, J. H. 2013. Physiological responses to shifts in multiple environmental stressors: relevance in a changing world. Integr. Comp. Biol. 53:539-544.

Tsai, J.-R., and Lin, H.-C. 2007. V-type $\mathrm{H}^{+}$-ATPase and $\mathrm{Na}^{+}, \mathrm{K}^{+}$-ATPase in the gills of 13 euryhaline crabs during salinity acclimation. J. Exp. Biol. 210:620-627.

Weihrauch, D., Ziegler, A., D., and Towle, D. W. 2001. Molecular characterization of V-type $\mathrm{H}^{+}$-ATPase ( $\beta$-subunit) in gills of euryhaline crabs and its physiological role in osmoregulatory ion uptake. J. Exp. Biol. 204:25-37. 


\section{LIST OF FIGURES}

348 Figure 1: Haemolymph $\mathrm{Na}^{+}$(white bars; $n=8-12$ ) and $\mathrm{Cl}^{-}$(grey bars; $n=18-22$ ) concentrations, 349 and total osmolality (black bars; $n=8-12$ ) in Sesarma reticulatum after a 48-hour exposure to 350 varying combinations of $\mathrm{pH}$ and salinity conditions. Salinity is indicated by striped (5\%) or 351 solid (30\%) patterns. Data are presented as mean \pm s.e.m. Letters indicate differences in total 352 osmolality across varying ambient conditions (two-way ANOVA; Tukey's post-hoc). There were 353 no significant differences in $\left[\mathrm{Na}^{+}\right]$or $\left[\mathrm{Cl}^{-}\right]$between experimental conditions (Tukey's post-hoc).

355 Figure 2: Gill $\mathrm{Na}^{+} / \mathrm{K}^{+}$-ATPase activity (white bars; NKA; $n=16-18$ ) and V-type $\mathrm{H}^{+}$-ATPase 356 activity (grey bars; VHA; $n=6-8$ ) in Sesarma reticulatum after a 48-hour exposure to varying 357 combinations of $\mathrm{pH}$ and salinity conditions. Salinity is indicated by striped (5\%o) or solid (30 $358 \%$ ) patterns. Data are presented as mean \pm s.e.m. There were no significant differences in NKA 359 or VHA between experimental conditions (Tukey’s post-hoc). 


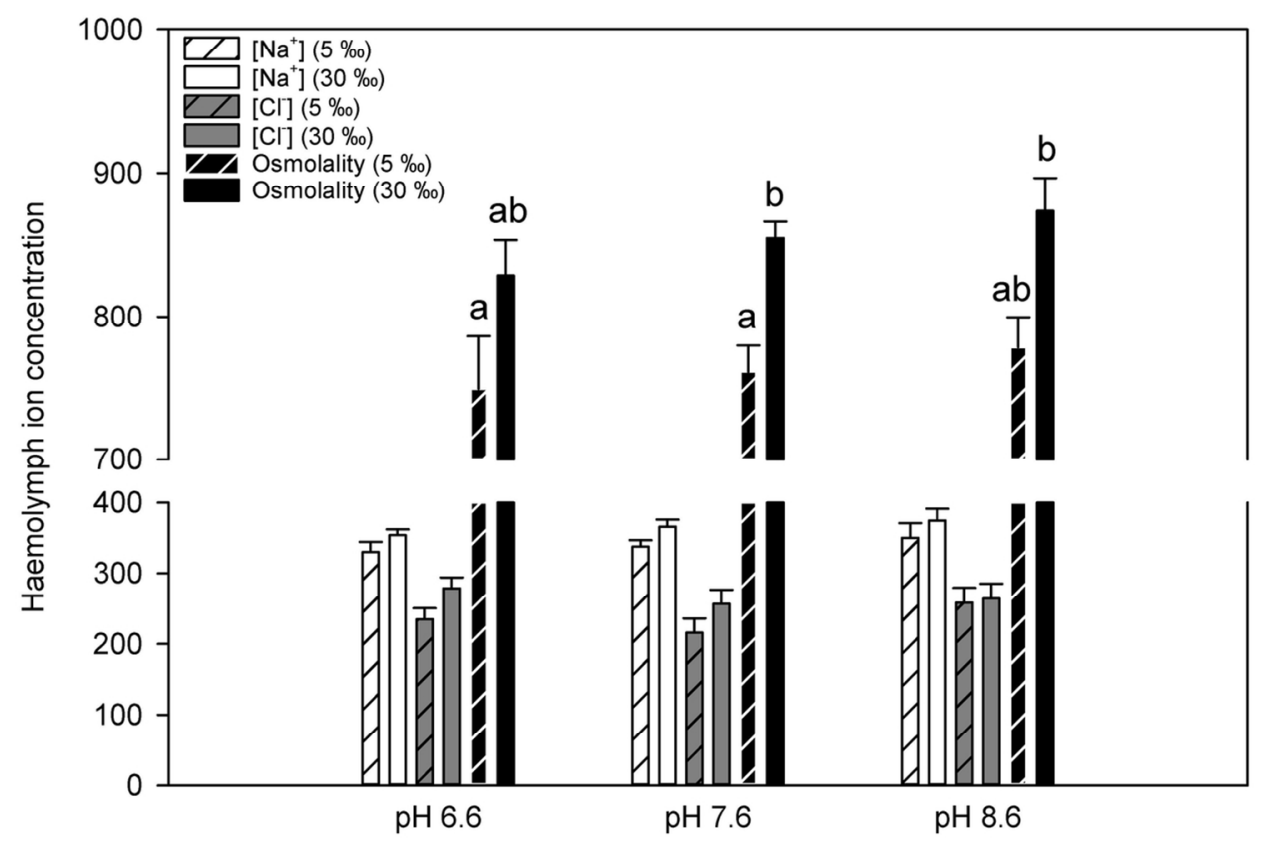

Haemolymph $\mathrm{Na}^{+}$(white bars; $n=8-12$ ) and $\mathrm{Cl}^{-}$(grey bars; $n=18-22$ ) concentrations, and total osmolality (black bars; $n=8-12$ ) in Sesarma reticulatum after a 48 -hour exposure to varying combinations of $\mathrm{pH}$ and salinity conditions. Salinity is indicated by striped (5\%o) or solid (30\%o) patterns. Data are presented as mean \pm s.e.m. Letters indicate differences in total osmolality across varying ambient conditions (two-way ANOVA; Tukey's post-hoc). There were no significant differences in $\left[\mathrm{Na}^{+}\right]$or $\left[\mathrm{Cl}^{-}\right]$ between experimental conditions (Tukey's post-hoc).

$112 \times 82 \mathrm{~mm}(300 \times 300 \mathrm{DPI})$ 


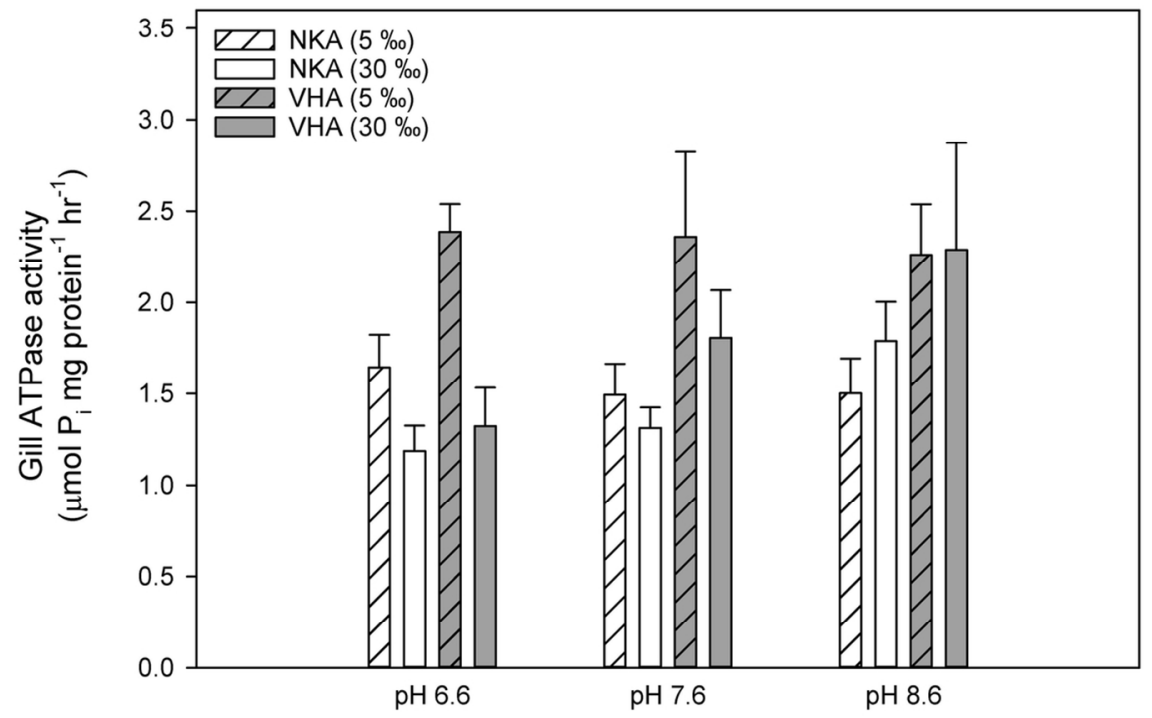

Gill $\mathrm{Na}^{+} / \mathrm{K}^{+}$-ATPase activity (white bars; NKA; $n=16-18$ ) and V-type $\mathrm{H}^{+}$-ATPase activity (grey bars; VHA; $n$ $=6-8$ ) in Sesarma reticulatum after a 48-hour exposure to varying combinations of pH and salinity conditions. Salinity is indicated by striped (5\%o) or solid (30\%o) patterns. Data are presented as mean \pm s.e.m. There were no significant differences in NKA or VHA between experimental conditions (Tukey's posthoc).

$113 \times 73 \mathrm{~mm}(300 \times 300 \mathrm{DPI})$ 